кандидат наук з фізичного виховання та спорту (Житомирський військовий інститут імені С. П. Корольова) prontenko-kostya@ukr.net ORCID: 0000-0002-0588-8753

Г. П. Грибан, доктор педагогічних наук, професор (Житомирський державний університет імені Івана Франка) gribang@ukr.net ORCID: 0000-0002-9094-1485

В. В. Пронтенко, кандидат наук з фізичного виховання та спорту (Житомирський військовий інститут імені С. П. Корольова) prontenko.v@gmail.com ORCID: 0000-0003-2454-6190

С. В. Гоманюк

(Військовий інститут танкових військ Національного технічного університету "Харківський політехнічний інститут") fiz_sporteukr.net ORCID: $0000-\overline{0} 001-7704-0105$

\title{
ВПЛИВ ЗАНЯТЬ ГИРЬОВИМ СПОРТОМ НА ФІЗИЧНУ ПІДГОТОВЛЕНІСТЬ КУРСАНТІВ ВІЙСЬКОВИХ ЗАКЛАДІВ ВИЩОЇ ОСВІТИ УКРАЇНИ
}

У статті досліджено вплив занять гирьовим спортом на рівень фізичної підготовленості курсантів вищих військових навчальних закладів (ВВНЗ) у процесі навчання. У дослідженні взяли участь курсанти 1 - 5-х курсів (n=474), які займалися за чинною системою фізичної підготовки у ВВНЗ (група A, $n=416)$, та курсантів, які у процесі навчання займалися у секиї навчального закладу з гирьового спорту (група Б, $n=58)$. Виявлено найбільш виражений позитивний ефект від занять гирьовим спортом на розвиток силових якостей, статичної витривалості м'язів тулуба, витривалості та гнучкості у курсантів групи

Б. У тестах на виявлення вказаних якостей результати курсантів-гирьовиків на старших курсах $\epsilon$ достовірно кращі, ніж у курсантів, які займалися за чинною системою фізичної підготовки $(P<0,05-$

0,001). Це свідчить про позитивний вплив занять гирьовим спортом на фізичну підготовленість курсантів - майбутніх офіцерів Збройних Сил Украӥни.

Ключові слова: фізична підготовка, фізична підготовленість, курсант, гирьовий спорт.

Постановка проблеми. Сучасна військово-професійна діяльність випускників вищих військових навчальних закладів відбувається в екстремальних умовах зовнішнього середовища за наявності таких несприятливих чинників, як: постійне перебування у стані нервового і фізичного напруження, у стані втоми і стресу; низька рухова активність під час довготривалого перебування в умовах обмеженого простору (блокпости, кунги, бліндажі); перенесення на собі значної ваги (зброя, спорядження, боєприпаси); необхідність діяти вночі, за будь-якої погоди і на будь-якій місцевості; нерегламентованість рухового режиму та інші. Вплив несприятливих чинників призводить до суттєвих негативних змін в організмі військовослужбовців. Крім того, відсутність систематичних занять із фізичної підготовки у зоні бойових дій та належної матеріальної бази спричиняють такі наслідки, як: порушення обміну речовин та збільшення маси тіла (поява зайвої ваги), зниження рівня фізичної підготовленості та погіршення стану здоров'я, підвищення травматизму (особливо, опорно-рухового апарату), виникнення різних захворювань, погіршення показників психологічного стану. Це обумовлює необхідність удосконалення системи фізичної підготовки у ВВНЗ з метою підвищення рівня фізичної підготовленості курсантів та забезпечення високої ефективності їх майбутньої військово-професійної діяльності.

Аналіз основних досліджень і публікацій. У дослідженнях низки вчених $[1,2,3]$ встановлено, що чим вищий рівень фізичної підготовленості у військовослужбовця, тим ефективніше відбувається його професійна діяльність, при цьому у процесі служби показники здоров'я і професійно важливих психологічних якостей залишаються стабільними, порівняно із військовослужбовцями з низьким рівнем фізичної підготовленості.

Аналіз літературних джерел $[4,5,6]$ показав, що ефективним засобом фізичної підготовки курсантів ВВН3, а також військовослужбовців у період ведення бойових дій може бути гирьовий спорт, який наділений рядом переваг: відсутність значних матеріальних затрат; компактність інвентаря; можливість проведення тренування як в обмеженому просторі, так і на відкритій місцевості; можливість проведення як самостійного тренування так, і заняття одночасно з великою групою осіб; широкий діапазон простих і

(C) Пронтенко К. В., Грибан Г. П., Пронтенко В. В., Гоманюк С. В., 2018 
доступних вправ виключає можливість адаптації до однотипного навантаження; можливість проводити заняття одночасно 3 військовослужбовцями 3 різним рівнем фізичної підготовленості, висока ефективність щодо розвитку фізичних і морально-вольових якостей, зміцнення м'язів спини та усього тіла; профілактика травмування хребта і суглобів [7, 8].

Так, у ряді досліджень [4-6, 9, 10] встановлено, що заняття гирьовим спортом сприяють розвитку сили, загальної та силової витривалості, гнучкості, координації рухів, підвищенню фізичної працездатності, формуванню морально-вольових та психологічних якостей студентів ВНЗ. Оптимальне поєднання у тренувальному процесі засобів гирьового спорту та вправ, спрямованих на розвиток витривалості, підвищує рівень працездатності студентів. Під час виконання як фізичної, так і розумової праці, стомлення у гирьовиків настає значно пізніше, ніж у їхніх однолітків. Вправи з гирями, які виконуються 3 нахилом тулуба, за багаторазового виконання прирівнюються до бігу у помірному темпі, що сприяє зміцненню серцево-судинної системи та системи дихання. Нахили відмінно "прокачують" кров навколо хребта, що оздоровлює його та усі внутрішні органи, функціонування яких знаходиться у прямій залежності від стану хребта. Вправи з гирями здійснюють благотворний вплив на м'язи та кістковозв'язковий апарат військовослужбовців; сприяють поліпшенню пропорційності тіла, формують невимушену, правильну поставу. Систематичні заняття з гирями підвищують впевненість у своїх силах, розвивають такі морально-вольові якості, як, сміливість, рішучість, наполегливість, цілеспрямованість, витримка, воля до перемоги. Заняття гирьовим спортом (систематичні тренування та участь у змаганнях) пред’являють підвищені вимоги до організму, створюють стресові ситуації та викликають мобілізацію резервних можливостей організму курсантів. Напружені стресові ситуації змагальної діяльності стимулюють розвиток морально-вольових процесів людини, формують його характер, вчать стійко долати труднощі. Під час занять з гирями відбувається розвиток психічних якостей, що передбачає єдність впливів на мотиваційну, інтелектуальну, вольову, емоційну і дієво-практичну сферу курсанта, що забезпечує формування не тільки знань, умінь і навичок, але й мотивів, потреб, переконань особистості у доцільності своєї діяльності, яка часто пов'язана зі свідомим подоланням фізичних навантажень. Вольові якості особистості, які виховані у процесі занять гирьовим спортом, ефективно виявляються у професійній діяльності [3, 8, 9]. Тому дослідження рівня фізичної підготовленості курсантів, які займалися гирьовим спортом, та порівняння його з рівнем курсантів, які займалися за чинною системою фізичної підготовки у процесі навчання, є своєчасним та актуальним.

Організація, мета і методи дослідження. У дослідженні взяли участь 474 курсанти 1-5-х курсів Житомирського військового інституту імені С. П. Корольова, які займалися за чинною системою фізичної підготовки у ВВНЗ (група А, n=416), та курсантів, які займалися гирьовим спортом у секції інституту (група Б, n=58). Було досліджено рівень фізичної підготовленості курсантів обох груп. Тестування показників фізичної підготовленості курсантів проводилося за такими вправами: біг на 100 м (швидкісні якості), підтягування на перекладині (силові якості), біг на 3 км (загальна витривалість), загальна контрольна вправа на смузі перешкод (400м, координаційні здібності, спритність, спеціальні якості), комплексно-силова вправа (згинання і розгинання рук в упорі лежачи протягом 1 хв. та піднімання вслід протягом 1 хв., силові якості), нахил тулуба вперед із положення сидячи (гнучкість), утримання тулуба у горизонтальному положенні (статична витривалість м'язів тулуба). Перевірка вправ здійснювалася викладачами кафедри фізичного виховання, спеціальної фізичної підготовки і спорту під час контрольних занять (заліків, екзаменів). Під час досліджень визначалася достовірність різниці між показниками курсантів групи А і Б за допомогою критерію Стьюдента, а також оцінювалася величина змін результатів у кожній з груп.

Мета статті - дослідити вплив занять гирьовим спортом на показники фізичної підготовленості курсантів вищих військових навчальних закладів у процесі навчання.

Методи дослідження: теоретичний аналіз та узагальнення наукової і методичної літератури, педагогічне спостереження, тестування, методи математичної статистики.

Виклад основного матеріалу. Аналіз результатів з бігу на 100 м показав, що на 1-му курсі навчання у ВВНЗ результати курсантів обох груп між собою достовірно не відрізнялися $(\mathrm{P}>0,05)$ (табл. 1). На 4-му і 5-му курсах результати курсантів, які займалися за чинною системою фізичної підготовки, виявилися достовірно кращими, ніж у групі курсантів-гирьовиків на 0,4 та 0,5 с відповідно $(\mathrm{P}<0,05)$. Аналізуючи зміни швидкісних показників у курсантів кожної групи окремо, слід зазначити, що у групі А на 5-му курсі результати з бігу на 100 м є достовірно кращими, ніж на 1 -му, на 0,9 с $(\mathrm{P}<0,001)$. У групі Б результати курсантів випускного курсу також переважають результати першокурсників на 0,3 с, але достовірної різниці між ними не виявлено $(\mathrm{P}>0,05)$ (табл. 1). При цьому рівень розвитку швидкісних якостей у курсантів групи А на 1-му і 2-му курсах оцінюється на оцінку "добре", а на старших курсах на "відмінно". У групі Б рівень швидкісних якостей на всіх курсах оцінений на "добре". 
Таблиия 1

Динаміка показників фізичної підготовленості у курсантів, які займалися за чинною системою фізичної підготовки (група А), та курсантів, які займалися у секції з гирьового спорту (група Б),

\begin{tabular}{|c|c|c|c|c|c|}
\hline \multirow{3}{*}{$\begin{array}{c}\text { Курс } \\
\text { навчання }\end{array}$} & \multirow{2}{*}{\multicolumn{2}{|c|}{ Група А $(\mathrm{n}=416)$}} & & & \\
\hline & & & \multicolumn{2}{|c|}{ Група Б (n=58) } & \multirow{2}{*}{$\begin{array}{r}\text { Рівень } \\
\text { значущості }\end{array}$} \\
\hline & $\mathrm{n}$ & $\mathrm{X} \pm \mathrm{m}$ & $\mathrm{n}$ & $\mathrm{X} \pm \mathrm{m}$ & \\
\hline \multicolumn{6}{|c|}{ Біг на $100 \mathrm{M}, \mathrm{c}$} \\
\hline 1 & 62 & $14,6 \pm 0,12$ & 16 & $14,5 \pm 0,13$ & $\mathrm{P}>0,05$ \\
\hline 2 & 112 & $14,3 \pm 0,08$ & 9 & $14,4 \pm 0,16$ & $\mathrm{P}>0,05$ \\
\hline 3 & 91 & $14,0 \pm 0,10$ & 14 & $14,3 \pm 0,13$ & $\mathrm{P}>0,05$ \\
\hline 4 & 76 & $13,8 \pm 0,11$ & 12 & $14,2 \pm 0,14$ & $\mathrm{P}<0,05$ \\
\hline 5 & 65 & $13,7 \pm 0,12$ & 7 & $14,2 \pm 0,16$ & $\mathrm{P}<0,05$ \\
\hline \multicolumn{6}{|c|}{ Підтягування на перекладині, рази } \\
\hline 1 & 62 & $12,1 \pm 0,75$ & 16 & $13,7 \pm 0,93$ & $\mathrm{P}>0,05$ \\
\hline 2 & 112 & $14,3 \pm 0,48$ & 9 & $15,8 \pm 1,04$ & $\mathrm{P}>0,05$ \\
\hline 3 & 91 & $16,1 \pm 0,61$ & 14 & $19,2 \pm 0,96$ & $\mathrm{P}<0,05$ \\
\hline 4 & 76 & $17,3 \pm 0,72$ & 12 & $21,9 \pm 1,02$ & $\mathrm{P}<0,001$ \\
\hline 5 & 65 & $18,2 \pm 0,78$ & 7 & $24,0 \pm 1,06$ & $\mathrm{P}<0,001$ \\
\hline \multicolumn{6}{|c|}{ Біг на 3 км, с } \\
\hline 1 & 62 & $789,3 \pm 8,19$ & 16 & $795,2 \pm 13,42$ & $\mathrm{P}>0,05$ \\
\hline 2 & 112 & $757,4 \pm 7,66$ & 9 & $729,4 \pm 13,17$ & $\mathrm{P}>0,05$ \\
\hline 3 & 91 & $735,2 \pm 7,93$ & 14 & $705,7 \pm 12,10$ & $\mathrm{P}<0,05$ \\
\hline 4 & 76 & $722,1 \pm 7,86$ & 12 & $691,3 \pm 10,93$ & $\mathrm{P}<0,05$ \\
\hline 5 & 65 & $717,8 \pm 7,34$ & 7 & $681,6 \pm 11,21$ & $\mathrm{P}<0,01$ \\
\hline \multicolumn{6}{|c|}{ Загальна контрольна вправа на смузі перешкод, с } \\
\hline 1 & 62 & $143,1 \pm 1,69$ & 16 & $146,0 \pm 1,82$ & $\mathrm{P}>0,05$ \\
\hline 2 & 112 & $137,8 \pm 1,27$ & 9 & $137,4 \pm 2,73$ & $\mathrm{P}>0,05$ \\
\hline 3 & 91 & $132,2 \pm 1,34$ & 14 & $129,2 \pm 2,08$ & $\mathrm{P}>0,05$ \\
\hline 4 & 76 & $126,9 \pm 1,30$ & 12 & $122,8 \pm 2,65$ & $\mathrm{P}>0,05$ \\
\hline 5 & 65 & $123,3 \pm 1,52$ & 7 & $118,2 \pm 2,21$ & $\mathrm{P}<0,05$ \\
\hline \multicolumn{6}{|c|}{ Комплексно-силова вправа, рази } \\
\hline 1 & 62 & $52,2 \pm 2,17$ & 16 & $57,5 \pm 3,52$ & $\mathrm{P}>0,05$ \\
\hline 2 & 112 & $57,1 \pm 1,29$ & 9 & $63,8 \pm 3,76$ & $\mathrm{P}>0,05$ \\
\hline 3 & 91 & $59,8 \pm 1,78$ & 14 & $70,3 \pm 3,63$ & $\mathrm{P}<0,05$ \\
\hline 4 & 76 & $62,4 \pm 1,93$ & 12 & $76,2 \pm 3,27$ & $\mathrm{P}<0,01$ \\
\hline 5 & 65 & $64,5 \pm 1,84$ & 7 & $82,6 \pm 3,41$ & $\mathrm{P}<0,001$ \\
\hline \multicolumn{6}{|c|}{ Нахил тулуба сперед із положення сидячи, см } \\
\hline 1 & 62 & $6,8 \pm 0,58$ & 16 & $7,2 \pm 1,49$ & $\mathrm{P}>0,05$ \\
\hline 2 & 112 & $7,4 \pm 0,32$ & 9 & $13,8 \pm 1,17$ & $\mathrm{P}<0,001$ \\
\hline 3 & 91 & $8,8 \pm 0,35$ & 14 & $17,3 \pm 1,02$ & $\mathrm{P}<0,001$ \\
\hline 4 & 76 & $10,2 \pm 0,43$ & 12 & $18,2 \pm 0,91$ & $\mathrm{P}<0,001$ \\
\hline 5 & 65 & $10,4 \pm 0,37$ & 7 & $19,0 \pm 0,85$ & $\mathrm{P}<0,001$ \\
\hline \multicolumn{6}{|c|}{ Утримання тулуба у горизонтальному положенні, с } \\
\hline 1 & 62 & $94,3 \pm 4,25$ & 16 & $112,1 \pm 6,71$ & $\mathrm{P}<0,05$ \\
\hline 2 & 112 & $110,6 \pm 3,10$ & 9 & $199,8 \pm 8,27$ & $\mathrm{P}<0,001$ \\
\hline 3 & 91 & $127,1 \pm 3,57$ & 14 & $215,3 \pm 5,65$ & $\mathrm{P}<0,001$ \\
\hline 4 & 76 & $136,4 \pm 3,13$ & 12 & $221,9 \pm 5,42$ & $\mathrm{P}<0,001$ \\
\hline 5 & 65 & $142,9 \pm 4,06$ & 7 & $228,2 \pm 6,18$ & $\mathrm{P}<0,001$ \\
\hline
\end{tabular}

Дослідження результатів у підтягуванні на перекладині свідчить, що тільки на 1-му курсі рівень силових якостей курсантів обох груп між собою достовірно не відрізняється $(\mathrm{P}>0,05)$ (табл. 1). На 2-му курсі результати курсантів групи Б виявилися кращими, ніж у групі А на 1,5 разу, але різниця $\epsilon$ недостовірною (Р>0,05). На усіх інших курсах навчання результати курсантів, які займалися у секції $з$ гирьового спорту, виявилися достовірно кращими, ніж у курсантів, які займалися за чинною системою фізичної підготовки $(\mathrm{P}<0,05-0,001)$. Так, на 3-му курсі різниця між результатами курсантів груп А і Б становить 3,1 разу, на 4-му -4,6 разу, на 5-му $-5,8$ разу (рис. 1).

Аналіз результатів з бігу на 3 км показав, що на 1-му і 2-му курсах показники розвитку витривалості у курсантів обох груп між собою не мають достовірної різниці $(\mathrm{P}>0,05)$. Починаючи із 3-го курсу 
результати з бігу на 3 км у курсантів, які займалися гирьовим спортом, є достовірно кращими, порівняно із результатами курсантів, які займалися за чинною системою фізичної підготовки у ВВНЗ (P $<0,05-0,01)$. Так, на 3-му курсі результати групи Б переважають результати групи А на 29,5 с (Р<0,05), на 4-му курсі на 30,8 с $(\mathrm{P}<0,05)$, а на 5-му - на 36,2 с $(\mathrm{P}<0,01)$.

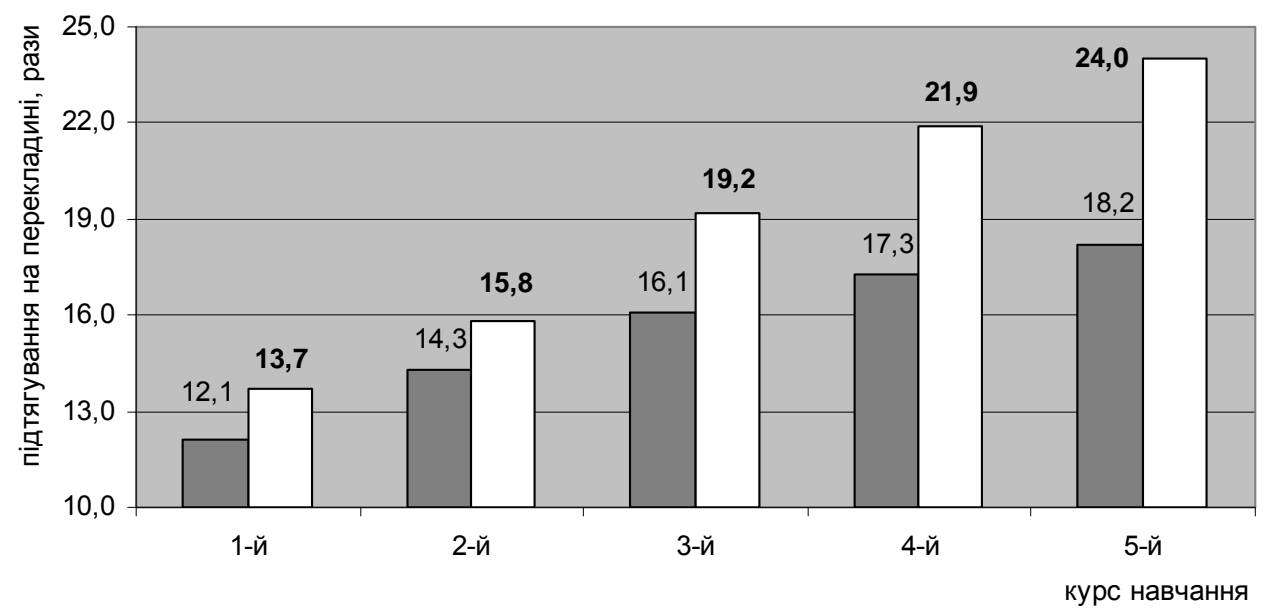

Рис. 1. Динаміка результатів 3 підтягування у курсантів, які займалися за чинною системою фізичної підготовки (група А), та курсантів, які займалися у секції ВВНЗ з гирьового спорту

результати курсантів групи А; (група Б), $(n=474$, рази):

Дослідження результатів виконання курсантами вправи на смузі перешкод (400 м) свідчить, що на 1му та 2-му курсах показники обох груп достовірно не відрізнялися $(\mathrm{P}>0,05)$. На 3-му і 4-му курсах результати курсантів групи Б є кращими, ніж у курсантів групи А на 3 та 4,1 с відповідно, але достовірної різниці не виявлено $(\mathrm{P}>0,05)$. На 5-му курсі результати групи Б виявилися достовірно кращими на 5,1 с $(\mathrm{P}<0,05)$. Перевірка результатів виконання курсантами комплексної силової вправи свідчить, що результати курсантів групи Б, особливо на старших курсах, є достовірно вищими, ніж у курсантів групи А на 10,5; 13,8 та 18,1 разу відповідно ( $<0,05-0,001)$. Найвищі результати у курсантів обох груп зафіксовано на 5-му курсів, що свідчить про поліпшення рівня фізичної підготовленості курсантів у процесі навчання у ВВН3 $(\mathrm{P}<0,001)$. Однак у групі курсантів групи А результати 5-го курсу переважають результати 1-го курсу на 12,3 разу, а у групі Б - на 25,1 разу. Досягнення високих результатів у гирьовому спорті крім сили та витривалості вимагає високого рівня розвитку гнучкості та рухливості у суглобах, тому у тренувальному процесі курсантів-гирьовиків значна увага надається розвитку цієї якості. Аналіз результатів курсантів у нахилі тулуба вперед показав, що у групі Б показники є достовірно кращими $(\mathrm{P}<0,05-0,001)$ ніж у курсантів групи А на усіх курсах, крім 1-го. На 2му курсі різниця між показниками курсантів груп А і Б становить 6,4 см, на 2-му - 8,5 см, на 3-му - 8 см, на 5-му - 8,6 см. Аналіз результатів курсантів в утриманні тулуба у горизонтальному положенні показав яскраво виражений вплив занять гирьовим спортом на зміцнення м'язів спини і пресу у гирьовиків. Так, починаючи вже із 1-го курсу результати виконання статичної вправи у курсантів групи Б є достовірно кращими ніж у курсантів групи А. Різниця між показниками курсантів групи Б і А становить: на 1-му курсі - 17,8 с; на 2-му - 89,2 с; на 3-му - 88,2 с; на 4-му - 85,5 с; на 5-му - 85,3 с (рис. 2). 


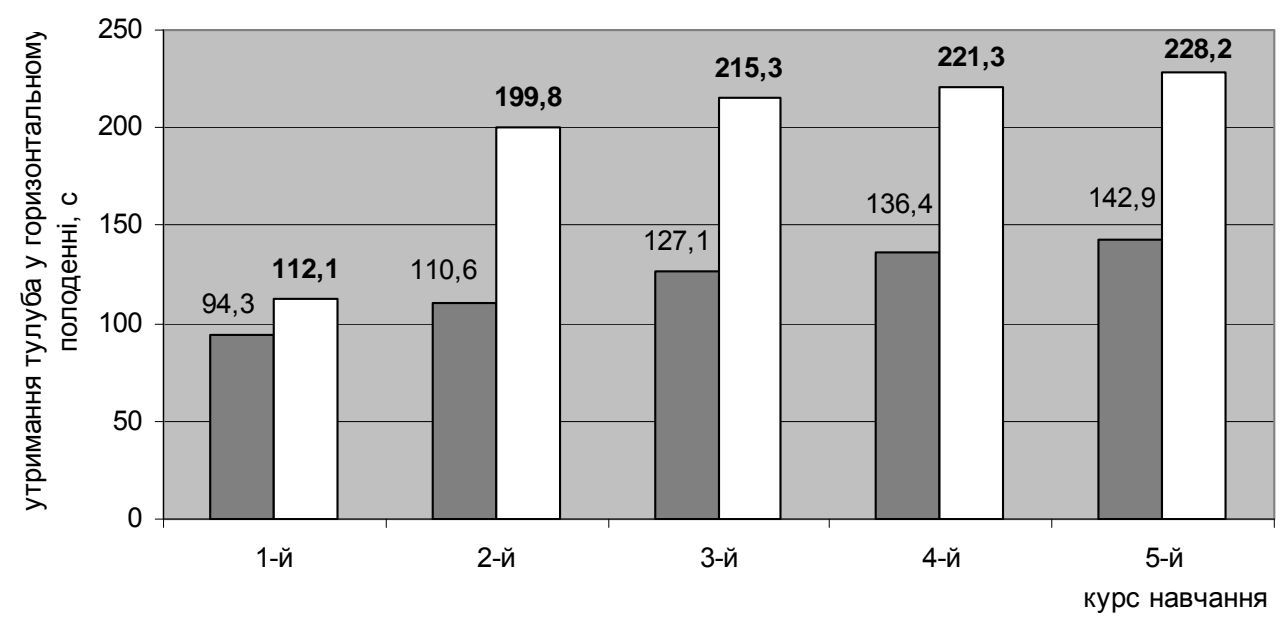

Рис. 2. Динаміка результатів в утриманні тулуба у горизонтальному положенні у курсантів, які займалися за чинною системою фізичної підготовки (група А), та курсантів, які займалися гирьовим спортом (група Б), $(\mathrm{n}=\mathbf{4 7 4}, \mathrm{c})$ :

результати курсантів групи А; результати курсантів групи Б

Обговорення результатів дослідження. Дослідження результатів з бігу на 100 м показали, що чинна система фізичної підготовки більш ефективно, порівняно із заняттями гирьовим спортом, впливає на розвиток швидкісних якостей курсантів ВВНЗ. Це підтверджує наші попередні висновки та результати вчених [2, 3, 7], у яких вказано про відсутність взаємозв'язку між результатами у гирьовому спорті і показниками розвитку швидкісних якостей. Аналіз результатів курсантів у підтягуванні показав, що як у групі А, так і у групі Б рівень силових показників на всіх курсах оцінюється на "відмінно" та зростає у процесі навчання. Але якщо у групі А результати курсантів 5-го курсу є кращими, ніж у курсантів 1-го курсу на 6,1 разу, то у групі Б різниця становить 10,3 разу. Це свідчить про більш виражений позитивний вплив занять гирьовим спортом на рівень розвитку силових якостей у курсантів у процесі навчання у ВВНЗ. Дослідження змін результатів з бігу на 3 км свідчить, що в обох групах зміни є позитивними: але якщо у групі А рівень розвитку витривалості у курсантів 5-го курсу (11 хв. 58 с) є достовірно кращим, ніж на 1-му (13 в 09 с) на 1 хв. 11 с $(\mathrm{P}<0,001)$, то у групі Б ці зміни мають більш виражений характер різниця між показниками курсантів 5-го курсу (11 хв 22 с) і 1-го курсу (13 хв. 15 с) становить 1 хв. 54 с $(\mathrm{P}<0,001)$. При цьому рівень розвитку витривалості у курсантів обох груп на 1-му курсі оцінювався як "задовільний", у групі А на 2-му, 3-му і 4-му курсах - як "добрий" і тільки на 5-му курсі - як "відмінний". У групі Б на 2-5-му курсах - оцінка "відмінно", що свідчить про позитивний вплив занять гирьовим спортом на рівень розвитку витривалості курсантів - майбутніх офіцерів. Порівняння отриманих результатів з подолання смуги перешкод 3 нормативними вимогами свідчить, що на 1-му курсі результати курсантів групи А оцінюються на "добре", а групи Б - на "задовільно", на 2-му курсі результати обох груп відповідають оцінці "добре", на старших курсах у групі А - "добре", а групі Б "відмінно". Це підтверджує висновки робіт багатьох вчених $[1,3,6]$ щодо позитивного впливу занять гирьовим спортом на розвиток усіх фізичних якостей та поліпшення спеціальної підготовленості курсантів. Аналіз показників гнучкості показав, що різниця між результатами курсантів 1-го і 5-го курсу у групі А становить 3,4 см, а у групі Б - 11,8 см, що підтверджує наші попередні висновки про позитивний вплив занять гирьовим спортом на рівень розвитку гнучкості у курсантів. Досліджуючи зміни результатів в утриманні тулуба у горизонтальному положенні, виявлено, що у групі А результати курсантів 5-го курсу (2 хв. 23 с) є кращими ніж у курсантів 1-го (1 хв. 34 с) на 48,6 с, то у групі Б різниця між показниками статичної витривалості курсантів 1-го (1 хв. 52 с) і 5-го (3 хв. 48 с) курсів становить 1 хв. 56 с. Таким чином проведений аналіз рівня розвитку фізичних якостей у курсантів ВВНЗ у процесі навчання підтвердив висновки багатьох вчених стосовно різностороннього позитивного впливу занять гирьовим спортом на організм курсантів - майбутніх офіцерів. Найбільш виражений позитивний ефект від занять гирьовим спортом виявлено на розвиток силових якостей, статичної витривалості м'язів тулуба, витривалості та гнучкості. Найменший вплив від занять гирьовим спортом виявлено на рівень розвитку швидкісних якостей - результати курсантів, які займалися за чинною системою фізичної підготовки на старших курсах є достовірно кращими ніж у гирьовиків.

Висновки.

1. Виявлено найбіш виражений позитивний ефект від занять гирьовим спортом на розвиток силових якостей, статичної витривалості м'язів тулуба, витривалості та гнучкості. У тестах на виявлення вказаних 
якостей результати курсантів-гирьовиків на старших курсах є достовірно кращі, ніж у курсантів, які займалися за чинною системою фізичної підготовки $(\mathrm{P}<0,05-0,001)$.

2. Встановлено, що заняття гирьовим спортом більш ефективно впливають на рівень фізичної підготовленості курсантів, ніж заняття за чинною системою фізичної підготовки у процесі навчання у BВH3.

Перспективи подальших досліджень полягають у обгрунтуванні та розробці моделі методичної системи навчання гирьовому спорту курсантів у процесі фізичної підготовки з метою забезпечення їх ефективної майбутньої військово-професійної (бойової) діяльності.

\section{СПИСОК ВИКОРИСТАНИХ ДЖЕРЕЛ ТА ЛІТЕРАТУРИ}

1. Фізичне виховання військовослужбовців : [навч. посіб.] / [М. Ф. Пічугін, Г. П. Грибан, В. М. Романчук та ін.]. - Житомир : ЖВІНАУ, 2011. - 820 с.

2. Factors That Determine the Necessity for Developing Skills Required by Cadets in Higher Education Institutions of the Aerospace Forces to Organize Their Kettlebell Self-Training / A. Bolotin, V. Bakayev, S. Vazhenin // Journal of Physical Education and Sport. - 2016. - 16 (1). - P. 102-108.

3. Development of the Physical Qualities of Future Specialists in Protective Activities due to the Use of the Kettlebell Sport During Studies / D. Kyslenko, K. Prontenko, V. Bondarenko, Iu. Yukhno, R. Radzievskii, V. Prontenko, O. Kiziun // Journal of Physical Education and Sport. - 2017. - 17 (2). - Art. 120. - P. 789-794.

4. Андрейчук В. Я. Методичні основи гирьового спорту : [навч. посібник] / В. Я. Андрейчук. - Львів : Тріада плюс, 2007. -500 с.

5. Гирьовий спорт у ВНЗ : [навч.-метод. посіб.] / [Г. П. Грибан, К. В. Пронтенко, В. В. Пронтенко та ін.]. Житомир : Вид-во "Рута", 2014. - 400 с.

6. Олешко В. Г. Підготовка спортсменів у силових видах спорту : [навч. посіб.] / В. Г. Олешко. - К. : ДІА, 2011. $-444 \mathrm{c}$.

7. Improvement of the Physical State of Cadets from Higher Educational Establishments in the Ukrainian Armed Forces due to the Use of the Kettlebell Sport / K. Prontenko, V. Prontenko, V. Bondarenko, S. Bezpaliy, G. Bykova, O. Zeleniuk, V. Dvoretsky // Journal of Physical Education and Sport. - 2017. - 17 (1). - Art. 67. - P. 447-451.

8. Morfofunctional State of Graduating Cadets of Higher Military Educational Establishments, which Went in for Weight Sport During Studying / K. Prontenko, S. Bezpaliy, R. Mihalchuk, S. Popov // Slobozhansk Herald of Science and Sport : [Scientific and Theoretical Journal]. - Kharkiv : KSAPC, 2014. - № 3 (41). - P. 92-98.

9. Організація та методика проведення занять з гирьового спорту : [навч.-метод. посібник] / В. М. Романчук, С. В. Романчук, К. В. Протенко, В. В. Протенко. - Житомир : ЖВІ НАУ, 2010. - 196 с.

10. Correlation Analysis of Indicators of Athletes' Readiness and their Competitive Results in Kettlebell Sport / K. Prontenko, G. Griban, V. Prontenko, S. Bezpaliy, V. Bondarenko, V. Andreychuk, P. Tkachenko // Journal of Physical Education and Sport. - 2017. - 17 (Supplement Issue 4). - Art. 217. - P. 2123-2128.

\section{REFERENCES (TRANSLATED \& TRANSLITERATED)}

1. Fizuchne vykhovannia viis'kovosluzhbovtsiv [Physical Education of Servicemen] : [navch. posib / [M. F. Pichugin, G. P. Griban, V. M. Romanchuk ta in.]. - Zhytomir : ZhVINAU, 2011. - 820 s.

2. Factors that Determine the Necessity for Developing Skills Required by Cadets in Higher Education Institutions of the Aerospace Forces to Organize Their Kettlebell Self-Training / A. Bolotin, V. Bakaiev, S. Vazhenin // Journal of Physical Education and Sport. - 2016. - 16 (1). - P. 102-108.

3. Development of the Physical Qualities of Future Specialists in Protective Activities due to the Use of the Kettlebell Sport During Studies / D. Kyslenko, K. Prontenko, V. Bondarenko, Iu. Yukhno, R. Radzievskii, V. Prontenko, O. Kiziun // Journal of Physical Education and Sport. - 2017. - 17 (2). - Art. 120. - P. 789-794.

4. Andreichuk V. Ya. Metodychni osnovy girovogo sportu [Methodical Bases of Kettlebell Lifting] : [navch. posib.] / V. Ya. Andreichuk. - Lviv : Triada plus, 2007. - $500 \mathrm{~s}$.

5. Girovui sport u VNZ [Kettlebell Lifting at HEE] : [navch.-metod. posib.] / G. P. Griban, K. V. Prontenko, V. V. Prontenko [ta in.]. - Zhytomir : "Ruta", 2014. - $400 \mathrm{~s}$.

6. Oleshko V. G. Pidgotovka sportsmeniv u silovikh vidakh sportu [The Preparedness of Sportsmen in the Power Types of Sport] : [navch. posib.] / V. G. Oleshko. - K. : DIA, 2011. - 444 s.

7. Improvement of the Physical State of Cadets from Higher Educational Establishments in the Ukrainian Armed Forces due to the use of the Kettlebell Sport / K. Prontenko, V. Prontenko, V. Bondarenko, S. Bezpalii, G. Bykova, O. Zeleniuk, V. Dvoretsky // Journal of Physical Education and Sport. - 2017. - 17 (1). - Art. 67. - P. 447-451.

8. Morfofunctional State of Graduating Cadets of Higher Military Educational Establishments, which Went in for Weight Sport During Studying / K. Prontenko, S. Bezpalii, R. Mihalchuk, S. Popov // Slobozhansk Herald of Science and Sport : [Scientific and Theoretical Journal]. - Kharkiv : KSAPC, 2014. - № 3 (41). - P. 92-98.

9. Organizatsiia ta metodika provedennia zaniat' $\mathrm{z}$ gyriovogo sportu [Organization and Methods of Conducting Kettlebell Lifting Training]: [navch.-metod. posib.] / V. M. Romanchuk, S. V. Romanchuk, K. V. Prontenko, V. V. Prontenko. - Zhytomir : ZhVINAU, 2010.-196 s.

10. Correlation Analysis of Indicators of Athletes' Readiness and their Competitive Results in Kettlebell Sport / K. Prontenko, G. Griban, V. Prontenko, S. Bezpaliy, V. Bondarenko, V. Andreychuk, P. Tkachenko // Journal of Physical Education and Sport. - 2017. - 17 (Supplement Issue 4). - Art. 217. - P. 2123-2128. 


\section{Пронтенко К. В., Грибан Г. П., Пронтенко К. В., Гоманюк С. В. Влияние занятий гиревым спортом} на физическую подготовленность курсантов военных заведений высиего образования Украины.

В статье исследовано влияние занятий гиревым спортом на уровень физической подготовленности курсантов выстих военных учебных заведений (ВВУЗ) в прочессе обучения. В исследовании приняли участие курсанты 1-5-х курсов (n=474), которые занимались по действующей системе физической подготовки в ВВУЗ (группа $A, n=416)$, и курсантов, которые в прочессе обучения занимались в секции учебного заведения по гиревому спорту (группа $Б, n=58)$. Выявлен наиболее выраженный положительный эффект от занятий гиревым спортом на развитие силовых качеств, статической выносливости мыши туловища, выносливости и гибкости у курсантов группы Б. В тестах на исследование указанных качеств результаты курсантов-гиревиков на стариих курсах являются достоверно лучшими чем у курсантов, которые занимались по действующей системе физической подготовки $(P<0,05-0,001)$. Это свидетельствует о положительном влиянии занятий гиревым спортом на физическую подготовленность курсантов - будущиих офицеров Вооруженных Сил Украины.

Ключевые слова: физическая подготовка, физическая подготовленность, курсант, гиревой спорт.

\section{Prontenko K. V., Griban G. P., Prontenko V. V., Gomaniyk S. V. The Influence of the Kettlebell Lifting Activities on the Physical Preparedness of Cadets of Higher Military Educational Institution of Ukraine.}

The influence of the kettlebell lifting activities on the physical preparedness level of cadets of higher military educational institution (HMEI) during the learning process was examined. Cadets of the $1^{\text {st }}-5^{\text {th }}$ year of study $(n=474)$ of Zhytomyr Military Institute named after S. P. Koroliov who were studying according to the current system of physical training at HMEI (group $A, n=416)$ and cadets who were attending a kettlebell lifting class while the studying (group $B, n=58$ ) took part in the investigation.

The level of physical preparedness was examined via the following tests: $100 \mathrm{~m}$ of running (speed qualities), pulling up on a cross-beam (strength qualities), $3 \mathrm{~km}$ of running (general endurance), overcoming an obstacle course (400 m) (coordination abilities, dexterity, special qualities), complex power exercise (dip ups during a minute and sit-ups during a minute) (strength qualities), forward inclination of the body in a seating position (flexibility), holding the body in a horizontal position (static endurance of body muscles). The examination of the exercises was held by the instructors of department of physical education, special physical training and sport during control matching (tests, examinations).

The aim of the article is to examine the influence of the kettlebell lifting activities on the indicators of physical preparedness of cadets of higher military educational institutions in the learning process.

Such research methods as theoretical analysis and generalization of scientific and methodical literature, pedagogical supervision, testing, and methods of mathematical statistics were used.

The analysis of the level of development of physical qualities of the cadets of HMEI in the process of study shows the various positive influences of the kettlebell lifting activities on the cadets and future officers' organisms. The most prominent positive effect of the kettlebell lifting activities is on the developing of strength qualities, static endurance of body muscles, endurance and flexibility. The least influence of the kettlebell lifting activities is on the level of speed qualities - the results of the cadets in the senior academic years who were studying according to the current system of physical training are credibly better than the results of cadets who were attending a kettlebell lifting class. The cadets in the senior courses exhibited better test results compared with cadets who were studying according to the current system of physical training $(P<0.05-0.001)$. It is determined that the kettlebell lifting activities have more effective influence on the level of physical preparedness of the cadets than the training according to the current system of physical training during the learning process in HMEI.

Key words: physical training, physical fitness, cadet, kettlebell lifting. 